\title{
MENINGKATKAN HASIL BELAJAR SISWA DALAM PERENCAAN PEMBELAJARAN MATEMATIKA SD
}

\author{
Wiwi Wiarsih \\ winarsihw014@gmail.com
}

\begin{abstract}
ABSTRAK: Penelitian bertujuan untuk meningkatkan hasil belajar siswa mata pelajaran Matematika Penggunaan metode prosedur pelaksanaanya terdiri dari empat langkah pada setiap siklusnya, yaitu perencanaan, pelaksanaan, pengamatan dan refleksi. Instrument yang digunakan yaitu lembar kerja siswa (LKS), lembar observasi siswa, lembar pengamatan guru, alat evaluasi hasil belajar dan lembar fefleksi, yaitu pernyataan-pernyataan berupa panduan untuk mengetahui pendapat teman sejawat. Kegiatan pembelajaran tidak hanya menilai hasil tetapi juga proses. Ini terlihat dalam kemampuan siswa dalam melakukan pembelajaran Matematika tentang penjumlahan dan pengurangan pada bilangan pecahan. Setelah dilakukan perbaikan-perbaikan proses pembelajaran dengan menerapkan Metode Drill hasil belajar siswa menunjukkan adanya perubahan yang signifikan.
\end{abstract}

Kata kunci: Metode Drill, Pembelajaran, Matematika, dan SD

\section{PENDAHULUAN}

Matematika merupakan salah satu bidang studi yang menduduki peranan penting dalam bidang pendidikan mulai dari SD sampai Perguruan Tinggi. Matematika bagi siswa SD berguna untuk kepentingan hidup pada lingkungannya, untuk mengembangkan pola pikirnya, dan untuk mempelajari ilmu-ilmu yang lain [1]. Pembelajaran Matematika di sekolah dasar merupakan peletak konsep dasar yang dijadikan landasan untuk belajar pada jenjang berikutnya. Selain itu, penguasaan matematika yang kuat sejak dini diperlukan untuk penguasaan dan penciptaan teknologi pada masa depan [2].

Pada kenyataannya pelajaran Matematika adalah pelajaran yang kurang disenangi oleh sebagian siswa, karena dianggap pelajaran yang sangat sulit sehingga hasil belajar matematika yang diperoleh masih kurang memuaskan. Untuk meningkatkan nilai pelajaran Matematika khususnya materi pecahan, guru perlu mengganti metode pembelajarannya. Metode yang akan digunakan adalah metode latihan dan metode drill. Dengan metode ini diharapkan dapat mencapai sasaran dan tujuan yang efektif serta efisien. 
Metode drill adalah metode dalam pengajaran dengan melatih peserta didik terhadap bahan yang sudah diajarkan dan diberikan agar memiliki ketangkasan atau keterampilan dari apa yang telah dipelajari [3]. Metode ini bertujuan agar daya pikir anak makin lama semakin bertambah baik, lebih teratur dan teliti dalam mendorong ingatannya. Selain itu pengetahuan anak akan bertambah, karena memperoleh pemahaman yang lebih baik dan mendalam.

\section{KAJIAN PUSTAKA}

\section{Pembelajaran Matematika di SD}

Secara etimologi, 'matematika' berasal dari bahasa Yunani yaitu Manthanein atau Mathema yang berarti belajar atau hal yang dipelajari. Dari pengertian tersebut dapat dikemukakan bahwa matematika merupakan pengetahuan yang tidak didapat dengan sendirinya. Pengetahuan mengenai matematika diperoleh seseorang setelah individu tersebut melalui proses belajar.

Menurut Ruseffendi dalam bahwa matematika adalah alat bantu dan pelayan ilmu lain, baik untuk kepentingan teoritis maupun untuk kepentingan praktis sebagai aplikasi dari matematika. Sebagai alat bantu dan pelayan ilmu lain mengandung arti bahwa matematika dapat digunakan sebagai alat untuk memecahkan masalah, cara berpikir, dan digunakan untuk berkomunikasi tentang pola-pola atau aturan, baik dalam kehidupan sehari-hari maupun dalam ilmu-ilmu lainnya. [4]

Pembelajaran matematika pada anak, harus disesuaikan dengan paradigma pendidikan bagi anak, khususnya anak SD. Strategi yang harus diimplementasikan dalam mengembangkan kedua objek dalam matematika, yakni objek langsung dan tidak langsung. Kedua objek tersebut merupakan penerapan pendekatan perkembangan anak. Artinya perkembangan anak harus menjadi dasar dalam memberikan pembelajaran Matematika.[21]

Ada empat tema yang melekat dengan pengajaran matematika di SD, yaitu matematika sebagai pemecah masalah, matematika sebagai komunikasi, matematika sebagai penalaran dan keterkaitan matematika. Dalam pembelajaran keterkaitan menunjukkan kepada tiga aspek, yakni keterkaitan di antara ide-ide matematika, keterkaitan dengan bidang studi lain, dan keterkaitan dengan dunia nyata. [5] Keterkaitan dengan dunia nyata memberikan pengertian kepada anak bahwa dengan 
belajar matematika tidak hanya mempelajari postulat-postulat atau aturan-aturan yang terkandung di dalamnya, melainkan belajar secara bermakna, bahwa matematika dapat digunakan dalam menyelesaikan persoalan dalam kehidupan sehari-hari anak. [6]

Matematika bagi siswa SD berguna untuk kepentingan hidup pada lingkungannya, untuk mengembangkan pola pikirnya, dan untuk mempelajari ilmuilmu yang lain. Manfaat lain yang menonjol dari matematika dapat membentuk pola pikir orang yang mempelajarinya menjadi pola pikir matematis yang sistematis, logis, dan kritis dengan penuh kecermatan [7]. Bahwa dalam pemebelajaran anak tidak bertindak dan berpikir sama seperti orang dewasa. [8]. Lebih-lebih pada pembelajaran matematika di SD, sesuatu yang abstrak dapat saja dipandang sederhana menurut kita yang sudah formal, namun dapat saja menjadi sesuatu yang sulit dimengerti oleh anak yang belum formal. Oleh karena itu, tugas utama sekolah ialah menolong anak mengembangkan kemampuan intelektualnya sesuai dengan perkembangan intelektual anak [9], [22]

Guru sebagai petugas profesional, sebagai seorang pendidik yang melakukan usaha untuk melaksanakan pendidikan terhadap sekelompok anak, tentunya harus memperhatikan dengan sungguh-sunggguh keadaan dasar anak didik tersebut.

\section{Metode Pembelajaran}

Metode berasal dari bahasa Greeka-Yunani, yaitu Metha (melalui atau melewati), dan Hodos (jalan atau cara). Asal kata makna tersebut metode memiliki pengertian sederhana adalah jalan atau cara yang ditempuh seorang guru dalam menyampaikan ilmu pengetahuan pada anak didiknya sehingga dapat mencapai tujuan tertentu. Metode adalah dalam interaksi pembelajaran adalah cara yang tepat dan cepat melakukan sesuatu. [10]

Menurut Roestiyah. N.K) guru harus memiliki strategi agar anak didik dapat belajar secara efektif dan efisien, mengena pada tujuan yang diharapkan. Dengan demikian metode mengajar adalah strategi pengajaran sebagai alat untuk mencapai tujuan yang diharapkan [11]

Sanjaya dan Sulfemi mengemukakan bahwa metode adalah cara yang digunakan untuk mengimplementasikan rencana yang sudah disusun dalam kegiatan nyata agar tujuan yang telah disusun tercapai secara optimal. [12].[13] 
Pendapat dari Thoifuri metode pengajaran adalah cara yang ditempuh guru dalam menyampaikan bahan ajar kepada siswa secara tepat dan cepat berdasarkan waktu yang telah ditentukan sehingga diperoleh hasil yang maksimal. \{14]

Metode mengajar dapat diartikan sebagai cara yang dipergunakan oleh pendidik dalam mengadakan hubungan dengan peserta didik pada saat berlangsungnya proses pembelajaran. Dengan demikian metode mengajar merupakan alat untuk menciptakan proses pembelajaran [23].

Beberapa ahli mendefinisikan metode, dalam Ramayulis adalah sebagai berikut:

a. Hasan Langgulung menyatakan bahwa metode adalah cara atau jalan yang harus dilalui untuk mencapai tujuan pendidikan.

b. Abd. Al-Rahman Ghunaimah berpendapat bahwa metode adalah cara-cara praktis dalam mencapai tujuan pengajaran.

c. Al-abrasyi mendefinisikan bahwa metode adalah jalan yang kita ikuti untuk memberikan pengertian kepada peserta didik tentang segala macam dalam berbagai pelajaran [15].

Berdasarkan uraian di atas, dapat disimpulkan bahwa metode adalah strategi yang harus diwujudkan atau dijalankan dalam proses belajar mengajar agar peserta didik dapat menerima materi ajar dengan mudah, efektif, dan dapat dicerna dengan baik.

Dengan memanfaatkan metode secara akurat, guru akan mampu mencapai tujuan pengajaran. Metode adalah pelicin jalan pengajaran menuju tujuan yang diharapkan. Jadi, guru sebaiknya menggunakan metode yang dapat menunjang kegiatan belajar mengajar [16], [24]

Upaya pendidik untuk memilih metode yang tepat dalam mendidik peserta didiknya harus disesuaikan dengan tuntutan dan karakteristik peserta didiknya. Guru harus mengusahakan agar pelajaran yang diberikan mudah diterima, berjalan baik dan efektif. Untuk itu, guru dituntut untuk mempelajari berbagai metode yang digunakan dalam mengajarkan suatu mata pelajaran.

Adapun jenis-jenis metode mengajar adalah sebagai berikut: 
a. Metode Proyek. Metode proyek atau unit adalah cara penyajian yang bertitik tolak dari suatu masalah, kemudian dibahas dari berbagai segi yang berhubungan sehingga pemecahannya secara keseluruhan dan bermakna.

b. Metode Eksperimen. Metode eksperimen adalah cara penyajian pelajaran yaitu siswa melakukan percobaan dengan mengalami dan membuktikan sendiri sesuatu yang dipelajari. Dalam proses belajar mengajar dengan metode percobaan ini. Siswa diberi kesempatan untuk mengalami sendiri, mengikuti suatu proses, mengamati suatu objek, keadaan, atau suatu proses sesuatu.

c. Metode Tugas dan Resitasi. Metode resitasi (penugasan) adalah metode penyajian bahan dimana guru memberikan tugas tertentu agar siswa melakukan kegiatan belajar. Tugas yang dilaksanakan oleh siswa dapat dilakukan di dalam kelas, di halaman sekolah, di laboratorium, di perpustakaan, di bengkel, di rumash siswa, atau dimana saja, asal tugas itu dapat dikerjakan oleh siswa.

d. Metode Diskusi. Metode diskusi adalah penyajian pelajaran dengan cara siswa dihadapkan kepada suatu masalah yang bisa berupa pernyataan atau pertanyaan yang bersifat problematis untuk dibahas dan dipecahkan bersama.

e. Metode Sosiodrama. Metode sosiodrama dan role playing, pada dasarnya mendramatisasikan tingkah laku dalam hubungan dengan hubungannya dengan masalah sosial. Tujuan penggunaan metode sosiodrama antara lain adalah agar siswa dapat menghayati dan menghargai perasaan orang lain, membagi tanggung jawab, mengambil keputusan dalam situasi kelompok secara spontan dan merangsang kelas untuk berpikir dan memecahkan masalah.

f. Metode Demontrasi. Metode demontrasi adalah cara penyajian pelajaran dengan memperagakan atau mempertunjukan kepada siswa suatu proses, situasi atau benda tertentu yang sedang dipelajari, baik sebenarnya ataupun tiruan yang sering disertai penjelasan lisan [18]

g. Metode Problem Solving. Metode problem solving (pemecahan masalah) merupakan metode berpikir, sebab dalam problem solving dapat menggunakan metode-metode lainnya yang dimalai dengan mencari data sampai menarik kesimpulan.

h. Metode Tanya Jawab. Metode Tanya jawab adalah cara penyajian pelajaran dalam bentuk pertanyaan yang harus dijawab, terutama dari guru kepada siswa, tetapi dapat pula dari siswa kepada guru. Metode Tanya jawab adalah metode 
tertua yang banyak digunakan dalam proses pendidikan, baik di lingkungan keluarga, masyarakat maupun sekolah.

i. Metode Karyawisata. Metode karya wisata adalah cara mengajar yang dilaksanakan dengan mengajak siswa ke suatu tempat atau objek tertentu di luar sekolah untuk mempelajari atau menyelidiki sesuatu seperti meninjau pabrik sepatu, atau ke bengkel mobil, atau suatu peternakan atau perkebunan, museum dan lain sebagainya.

j. Metode Ceramah. Metode ceramah adalah metode yang boleh dikatakan metode tradisional, karena sejak dulu metode ini digunakan sebagai alat komunikasi lisan antara guru dengan siswa dalam proses belajar mengajar. Metode ini banyak menuntut keaktifan guru dari pada siswa, tetapi metode ini tidak bisa ditinggalkan dalam kegiatan belajar mengajar, apalagi dalam pendidikan dan pengajaran tradisional, seperti dipedesaan yang kekurangan fasilitas.

k. Metode Latihan. Metode latihan yang disebut juga metode training, merupakan suatu cara mengajar yang baik untuk menanamkan kebiasaan-kebiasaan tertentu, juga sebagai sarana untuk memelihara kebiasaan-kebiasaan yang baik. Salain itu, metode ini juga dapat digunakan untuk memperoleh suatu ketangkasan, ketepatan, kesempatan, dan keterampilan. Tujuan menggunakan metode ini, salah satunya adalah untuk memperoleh kecakapan mental seperti dalam pembagian, perkalian, menjumlahkan, pengurangan, tanda-tanda (simbol-simbol) dan sebagainya. [17]

1. Metode Latihan/Drill. Menurut Thoifuri bahwa metode drill umumnya digunakan untuk memperoleh suatu ketangkasan atau keterampilan dari bahan yang dipelajari. Metode ini menekankan pada siswa untuk melaksanakan latihan/drill agar memiliki keterampilan yang lebih tinggi dari apa yang telah dipelajari. [14]

Menurut Roestiyah N.K teknik atau metode latihan atau drill ialah suatu teknik yang dapat diartikan sebagai suatu cara mengajar yaitu siswa melaksanakan kegiatan-kegiatan latihan, agar siswa memiliki ketangkasan atau keterampilan yang lebih tinggi dari apa yang telah dipelajari. Latihan yang praktis, mudah dilakukan, serta teratur melaksanakan pembinaan pada anak/siswa dalam meningkatkan 
penguasaan keterampilan itu, bahkan mungkin siswa dapat memiliki ketangkasan itu dengan sempurna [11].

Kelebihan metode ini di antaranya siswa dapat menguasai keterampilan yang diharapkan sehingga siswa mempunyai pengetahuan siap guna dan akan tertanam kebiasaan belajar secara rutin dan disiplin. Kelemahan metode ini di antaranya menghambat perkembangan daya inisiatif siswa, serta membentuk kebiasaan tidak fleksibel.

Teknik mengajar latihan/drill, digunakan untuk tujuan agar siswa:

a. Memiliki keterampilan motorik gerak; seperti menghafal kata-kata, menulis, mempergunakan alat dan sebagainya.

b. Mengembangkan kecakapan intelek, seperti mengalikan, membagi, menjumlahkan, mengurangi, menarik akar dalam hitungan congak dan sebagainya.

c. Memiliki kemampuan menghubungkan sesuatu keadaan dengan hal-hal seperti sebab akibat banyak hujan-banjir, penggunaan lambing/simbol di dalam peta dan sebagainya [11].

Dalam menggunakan teknik latihan/drill agar berhasil dan berdaya guna, perlu ditanamkan bagi guru maupun siswa ialah:

a. Tentang sifat-sifat suatu latihan, bahwa setiap latihan harus selalu berbeda dengan latihan sebelumnya. Hal itu disebabkan oleh situasi dan pengaruh yang berbeda, menurut daya tanggap/response yang berbeda pula. Bisa situasi latihan berubah, sehingga timbul tantangan yang dihadapi berlainan dengan situasi sebelumnya, maka memerlukan tanggapan yang berbeda pula.

b. Guru perlu memperhatikan dan memahami nilai dari latihan itu sendiri serta kaitannya dengan keseluruhan pelajaran disekolah. Dalam persiapan sebelum memasuki latihan guru harus memberikan pengertian dan perumusan tujuan yang jelas bagi siswa, sehingga mereka mengerti dan memahami apa tujuan latihan dan bagaimana kaitannya dengan pelajaran-pelajaran lain yang diterimanya [11]

Untuk kesuksesan pelaksanaan teknik latihan/drill itu, guru perlu memperhatikan langkah-langkah sebagai berikut:

a. Gunakan latihan ini hanya untuk pelajaran atau tindakan yang dilakukan secara otomatis, ialah yang dilakukan siswa tanpa menggunakan pemikiran dan 
pertimbangan yang meendalam. Tetapi dapat dilakukan dengan cepat seperti gerak reflex saja, seperti menghitung dan menghafal.

b. Guru harus memilih latihan yang mempunyai arti luas, ialah yang dapat menanamkan pengertian pemahaman akan makna dan tujuan latihan sebelum mereka melakukan.

c. Di dalam latihan pendahuluan guru harus lebih menekankan pada diagnose, karena letihan permulaan kita belum bisa menggharapkan siswa dapat menghasilkan keterampilan yang sempurna.

d. Perlu mengutamakan ketepatan, agar siswa melakuukan latihan secara tepat, kemudian diperhatikan kecepatannya, agar siswa dapat melakukan kecepatan dan keterampilan menurut waktu yang telah ditentukan.

e. Guru memperhitungkan waktu/masa latihan yang singkat saja agar tidak meletihkan dan membosankan tetapi sering dilakukan pada kesimpulan lain.

f. Guru dan siswa perlu memikirnkan dan mengutamakan proses-proses yang esensial/ pokok, sehingga tidak melakukan yang tidak diperlukan.

g. Guru perlu memperhatikan perbedaan individu siswa, sehingga kemampuan dan kebutuhan siswa masing-masing tersalur atau dikembangkan [19], [20]

Dengan langkah-langkah tersebut, diharapkan latihan dapat bermanfaaat bagi siswa untuk menguasai penguasaan pelajaran yang diterima baik secara teori maupun praktik di sekolah.

\section{PEMBAHASAN}

\section{Desain Prosedur Pembelajaran}

Rencana Perbaikan Pembelajaran yang akan dipergunakan adalah Kompetensi Dasar mata pelajaran Matematika, yaitu Melibatkan Operasi Hitung yang melibatkan berbagai bentuk pecahan. Indikator menentukan hasil penjumlahan/pengurangan/ perkalian/pembagian berbagai bentuk pecahan, dengan tujuan perbaikan pembelajaran siswa dapat melakukan penjumlahan dan pengurangan pada bilangan pecahan melalui penggunaan Metode Drill.

Untuk melengkapi penelitian disusun suatu instrumen yang akan digunakan dalam Penelitian Tindakan dalam bentuk:

1. Lembar Kerja Siswa (LKS). 
2. Lembar Observasi Siswa.

3. Lembar Pengamatan Guru.

4. Alat Evaluasi Hasil Belajar

5. Lembar Refleksi, yaitu pernyataan-pernyataan berupa panduan untuk mengetahui pendapat teman sejawat.

Dalam mengatasi kedua permasalahan di atas, peneliti melakukan perbaikan pembelajaran sebagai berikut

a. Perencanaan

Peneliti membuat rencana perbaikan pembelajaran berdasarkan refleksi siklus 1 untuk mencapai tujuan pembelajaran yang lebih baik. Hal-hal yang dipersiapkan adalah menyusun perangkat pembelajaran yang lebih lengkap sesuai tujuan dan membuat lembar observasi untuk mengamati partisipasi aktif siswa dalam pembelajaran.

b. Pelaksanaan

1) Pendahuluan (5 menit)

a) Mengkondisikan seluruh siswa untuk mengikuti pelajaran.

b) Menyebutkan tujuan pembelajaran.

c) Mengandalkan apersepsi dan memberikan motivasi agar siswa tertarik mempelajari materi yang akan dibahas.

2) Kegiatan Inti (25 menit)

a) Guru menjabarkan cara pengerjaan soal. Jika bilangan pecahan penyebutnya tidak sama, maka harus disamakan dengan menggunakan KPK. Setelah penyebutnya sama bilangan pecahan tersebut baru dapat dijumlahkan atau dikurangkan. Jika bilangan pecahan berbentuk pecahan campuran, bilangan tersebut harus dirubah menjadi bilangan pecahan biasa.

b) Dua atau tiga orang siswa diberi kesempatan untuk mencoba mengerjakan contoh soal di papan tulis.

c) Seluruh siswa mengerjakan soal-soal latihan di lembar tugas.

d) Guru memberikan kesempatan kepada siswa untuk bertanya tentang materi yang belum dipahaminya. 
e) Guru berkeliling memantau siswa yang sedang berlatih mengerjakan soal latihan

f) Guru memberikan penguatan kepada siswa terbaik supaya siswa termotivasi untuk menyelesaikan tugasnya.

g) Membahas soal secara bergilir di papan tulis.

h) Memberikan latihan kembali dengan soal bervariasi

i) Membahas kembali soal secara bergiliran

j) Pengambilan nilai.

3) Kegiatan Penutup (5 menit)

a) Menyimpulkan materi pelajaran.

b) Memberikan motivasi dan penguatan.

Peneliti melaksanakan rencana perbaikan pembelajaran sebagai berikut:

1) Guru menjelaskan kembali cara menyamakan penyebut yang berbeda dengan menggunakan KPK.

2) Memberikan kesembapatn kepada siswa untuk mengerjakan contoh soal di papan tulis.

3) Guru mengganti metode pembelajaran dari metode latihan menjadi metode drill.

4) Guru memberikan kesempatan kepada siswa untuk bertanya, agar siswa benarbenar memahami materi pelajaran.

5) Guru memberikan umpan balik positif dan penguatan/hadiah terhadap keberhasilan siswa terbaik dalam menyelesaikan tugas yang diberikan guru.

6) Memberikan latihan kembali dengan soal bervariasi

7) Guru dan siswa merefleksi hasil pembelajaran.

8) Mengadakan tes individu.

9) Mengadakan tindak lanjut, berupa pemberian tugas.

Peneliti melakukan pengamatan terhadap aktivitas siswa dalam mengikuti perbaikan dengan metode pembelajaran latihan dengan menggunakan metode drill. Hasil pengamatan ternyata ada perubahan yang cukup signifikan setelah menggunakan metode drill.

Berdasarkan pengalaman awal LKS yang dikerjakan dan hasilnya rata-rata diperoleh masih dibawah KKM, maka guru mengganti metode pembelajaran 
menggunakan Metode Drill. Selain itu, peneliti memberikan rewards (hadiah) kepada siswa yang dapat menyelesaikan tugasnya dengan cepat. Rewards yang diberikan bertujuan untuk memotivasi siswa lain agar meningkatkan hasil belajarnya.

\section{SIMPULAN}

Berdasarkan hasil aktivitas perbaikan pembelajaran yang telah dilaksanakan mulai dari penulis dapat menarik kesimpulan sebagai berikut:

1. Kegiatan pembelajaran tidak hanya menilai hasil tetapi juga proses. Ini terlihat dalam kemampuan siswa dalam melakukan pembelajaran matematika tentang penjumlahan dan pengurangan pada bilangan pecahan, setelah melakukan perbaikan-perbaikan proses pembelajaran dengan menerapkan Metode Drill hasil belajar siswa menunjukkan adanya perubahan yang signifikan.

2. Guru perlu terus meningkatkan kompetensinya. Dari hasil merefleksi aktivitas proses pembelajaran yang dilakukan guru sangat penting dengan tujuan untuk memperbaiki praktik pembelajaran di samping meningkatkan pelayanan pembelajaran bagi siswa. Oleh karena itu, guru harus mampu merancang pembelajaran secara matang, komprehensif dan sistematis. Mampu memilih dan menggunakan metode yang bervariasi dan tepat. Metode ini dapat membantu mempermudah pemahaman siswa pada proses pembelajaran. Memberikan bimbingan yang serius bagi para siswa dan melakukan pendekatan-pendekatan yang dapat mengbangkitkan keaktifan belajar siswa dalam pembelajaran.

\section{Daftar Pustaka}

[1] Sulfemi, W. B., \& Yuliana, D. (2019). Penerapan Model Pembelajaran Discovery Learning Meningkatkan Motivasi Dan Hasil Belajar Pendidikan Kewarganegaraan. Jurnal Rontal Keilmuan Pancasila dan Kewarganegaraan, 5(1), 17-30. Doi:http://dx.doi.org/10.29100/jr.v5i1.1021

[2] Supriyadi dkk. (2012). Modul Pendidikan dan Latihan Profesi Guru Sekolah Dasar Rayon 9 UNJ. Jakarta: Universitas Negeri Jakarta.

[3] Sulfemi, W. B., \& Kamalia, Y. (2020). Jigsaw Cooperative Learning Model Using Audiovisual Media To Improve Learning Outcomes. JPsd (Jurnal Pendidikan Sekolah Dasar). 6 30-42. DOI: http://dx.doi.org/10.30870/jpsd.v6i1.4919 
[4] Sudjana, Nana. (2009). Penilaian Hasil Proses Belajar Mengajar. Bandung: PT Remaja Rosdakarya.

[5] Sulfemi, Wahyu Bagja., \& Desmiati, Z. (2018). Model Pembelajaran Missouri Mathematics Project Berbantu Media Relief Experience dalam Meningkatkan Hasil Belajar Siswa. PENDAS MAHAKAM: Jurnal Pendidikan Dasar, 3(3), 232245. uwgm.ac.id/index.php/pendasmahakam/article/view/269/173 https://jurnal.fkip-

[6] Kurniasih, Imas dan Berlin Sani. (2015). Ragam Pengembangan Model Pembelajaran. Yogyakarta: Kata Pena.

[7] Wijaya, Surya. (2007). Ekslporasi Matematika Yang Mengasyikan: seri asyiknya olimpiade matematika untuk tingkat SD/MI. Tangerang: Kandel.

[8] Sulfemi, W. B., \& Minati, H. (2018). Meningkatkan Hasil Belajar Peserta Didik Kelas 3 SD Menggunakan Model Picture And Picture dan Media Gambar Seri. JPSD. 4 (2), 228- 242. DOI: http://dx.doi.org/10.30870/jpsd.v4i2.3857

[9] Sulfemi, Wahyu Bagja dan Yuliani, Nunung. (2019). Model Pembelajaran Contextual Teaching And Learning (CTL) Berbantu Media Miniatur Lingkungan Untuk Meningkatkan Hasil Belajar IPS. Edunomic. 7 (2). 73-84. DOI: $10.33603 /$ ejpe.v7i2.1970

[10] Arsyad, Arsyad dan Sulfemi, Wahyu Bagja. (2018) Metode Role Playing Berbantu Media Audio Visual Pendidikan dalam Meningkatkan Belajar IPS. Jurnal Pendidikan Ilmu Pengetahuan Sosial Indonesia. 3 (2). 41 - 46. DOI: http://dx.doi.org/10.26737/jpipsi.v3i2.1012

[11] Roestiyah, N. K. (2012). Strategi Belajar Mengajar. Jakarta: PT. Asdi Mahasatya.

[12] Sanjaya, Wina. (2014). Strategi Pembelajaran : Berorientasi Standar Proses Pendidikan. Jakarta. Prenadamedia Group.

[13] Sulfemi, Wahyu Bagja. (2018). Modul Manajemen Pendidikan Non Formal. Bogor: STKIP Muhammadiyah Bogor

[14] Sulfemi, Wahyu Bagja dan Nurhasanah. (2018). Penggunaan Metode Demontrasi dan Media Audio Visual Dalam Meningkatkan Hasil Belajar Peserta Didik Mata Pelajaran IPS. Jurnal Pendas Mahakam. 3 (2). 151-158. https://jurnal.fkipuwgm.ac.id/index.php/pendasmahakam/article/view/229

[15] Thoifuri. (2007). Menjadi Guru Inisiator. Semarang: Media Group.

[16] Ramayulis. (2015). Dasar-Dasar Kependidikan. Jakarta: Kalam Mulia.

[17] Sulfemi, Wahyu Bagja dan Setianingsih. (2018), Penggunaan Tames Games Tournament (TGT) Dengan Media Kartu Dalam Meningkatkan Hasil Belajar. Journal of Komodo Science Education (JKSE). 1 (1), 1-14. https://www.ejournal.stkipsantupaulus.ac.id/index.php/jkse/article/view/191 $/ 180$ 
[18] Sulfemi, Wahyu Bagja. (2018). Manajemen Kurikulum di Sekolah. Bogor : Visi Nusantara Maju

[19] Palettei, A. D., \& Sulfemi, Sulfemi, W. B. (2019). Pengaruh Kelompok Kerja Guru (KKG) Terhadap Peningkatan Kompetensi Pedagogik dan Kemampuan Menulis Karya Ilmiah. Jurnal Pendidikan Dasar Indonesia Jurnal Pendidikan Dasar

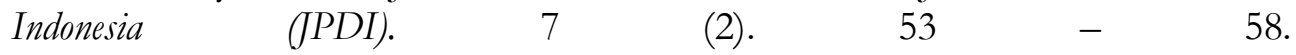
DOI: http://dx.doi.org/10.26737/jpdi.v4i2.1522

[20] Sulfemi, W. B., \& Mayasari, N. (2019). Peranan Model Pembelajaran Value Clarification Technique Berbantuan Media Audio Visual Untuk Meningkatkan Hasil Belajar IPS. Jurnal Pendidikan. 20 (1). 53-68. DOI: https://doi.org/10.33830/jp.v20i1.235.2019

[21] Sulfemi, Wahyu Bagja. (2019). Manajemen Pendidikan Berbasis Multi Budaya. Bogor : STKIP Muhammadiyah Bogor.

[22] Sulfemi, Wahyu Bagja. (2018). Pengaruh Disiplin Ibadah Sholat, Lingkungan Sekolah, dan Intelegensi Terhadap Hasil Belajar Peserta Didik Mata Pelajaran Pendidikan Agama Islam. Edukasi: Jurnal Penelitian Pendidikan Agama dan Keagamaan. $16 \quad$ (2), 166-178. https://jurnaledukasikemenag.org/index.php/edukasi/article/view/474/pdf

[23] Sulfemi, Wahyu Bagja. (2019). Model Pembelajaran Kooperatif Mind Mapping Berbantu Audio Visual Dalam Meningkatkan Minat, Motivasi dan Hasil Belajar IPS. Jurnal PIPSI Jurnal Pendidikan IPS Indonesia), 4(1), 13-19. DOI: http://dx.doi.org/10.26737/jipips.v4i1.1204

[24] Sulfemi, Wahyu Bagja dan Supriyadi, Dede. (2018). Pengaruh Kemampuan Pedagogik Guru dengan Hasil Belajar IPS. Edutecno 17 (1), 1-10

[25] Sulfemi, Wahyu Bagja. (2018). Hubungan Motivasi Belajar Dengan Hasil Belajar IPS Di SMP Kabupaten Bogor. Edutecno 18 (2), 1-8. 